\title{
SPIRITUAL QUOTIENT (SQ): THE ULTIMATE INTELLIGENCE
}

\author{
Rus'an \\ Sekolah Tinggi Agama Islam Negeri (STAIN) Datokarama Palu \\ Jalan Diponegoro No. 23 Palu \\ Email: humas@stain_palu.ac.id
}

\begin{abstract}
:
Tulisan ini membahas tentang kecerdasan spiritual sebagai puncak kecerdasan jauh melejit melebihi IQ dan EQ. IQ atau disebut Intelligence quotient adalah suatu bentuk kecerdasan yang bersandarkan nalar, rasio intelektual, yaitu cara berpikir secara linier yang meliputi kemampuan berhitung, menganalisa sampai mengevaluasi. Sementara EQ atau emotional Quotient bersandarkan emosional, yaitu kecerdasan yang mampu mengendalikan emosi dan memberi empati sehingga seseorang mampu bersikap wajar. Maka hakikat sejati SQ atau spiritual quotient disandarkan pada kecerdasan jiwa. Kecerdasan ini melahirkan kemampuan untuk menemukan makna hidup, serta memperhalus budi pekerti, SQ sebagai puncak kecerdasan menurut Danah Zohar, ini berarti bahwa makna kehidupan merupakan tujuan hidup yang pertama dan utama bagi manusia. Hanya orangorang cerdas secara spiritual mampu memberi makna dalam hidupnya.
\end{abstract}

\begin{abstract}
:
This paper discusses the spiritual intelligence as the ultimate intelligence which exceeds the IQ and EQ. IQ or intelligence quotient is a form of intelligence that based on reasoning, intellectual ratio, which is a linear way of thinking that includes the ability to count, analyze to evaluate. While EQ or Emotional Quotient based on emotional, namely the intelligence which is capable to control emotions and give empathy so a person is able to act natural. Therefore the true nature of the SQ or spiritual intelligence quotient was based on the soul. This intelligence makes people to have the ability to find meaning in life, as well as refine the manners. According to Danah Zohar SQ as the ultimate intelligence means that the meaning of life is the first and foremost goal of life for humans. Only intelligent people spiritually who can give meaning in his life.
\end{abstract}

Kata kunci:

Kecerdasan, intellectual quotient, spiritual quotient, emotional quotient

PADA umumnya masyarakat modern cenderung membuat hirarki status dan penghargaan berdasarkan intelejensi (kecerdasan) karena hal itu dianggap dapat mempengaruhi eksistensi seseorang dalam kehidupannya.

Sejak William Stern, psikolog Jerman, yang banyak mengacu pada teori intelejensi Alfred Binnet dan Theodore Simon yang membuat IQ (Intelligence Quotient) sebagai ukuran kecerdasan, sejak itu pula kemampuam matematis "merajai" dunia. Jarang penghargaan yang diberikan pada penulis puisi, novelis, olahragawan atau pelukis, sebagai orang-orang cerdas. Ukuran kecerdasan dan kunci kesuksesan hanyalah yang bertumpu pada nilai-nilia IQ (nilai rapor, IP). ${ }^{1}$ Itulah sebabnya IQ oleh Paul Eggen dianggap sebagai takdir, bahwa baik buruk nasib seseorang kelak ditentukan oleh IQ-nya yang tinggi, maka baik pula nasib yang bersangkutan. Demikian pula ji- 
ka IQ-nya rendah maka sudah menjadi takdir yang bersangkutan akan mengalami kehidupan sebagaimana IQ-nya tadi.

Apakah IQ, kunci kecerdasan masa depan? Betulkah IQ merupakan takdir, dan satu-satunya parameter kesuksesan hidup? Inilah yang mengundang tanda tanya Sukidi dalam bukunya New Age Wisata Spiritual Lintas Agama. ${ }^{2}$ Tidak! Inilah jawaban tegas Daniel Goleman. Fakta bicara lain dan bahkan berbalik total. Betapa banyaknya kenyataan kita jumpai di dunia ini yang menunjukkan hal yang sebaliknya. Seseorang yang memiliki IQ yang baik justru gagal dalam kehidupannya, sebaliknya banyak sekali orang yang sebenarnya hanya memiliki IQ biasa-biasa saja malah sukses dalam kehidupannya. Kenyataan tersebut menunjukkan bahwa terdapat faktor turut berpengaruh atau menentukan apakah seseorang nanti akan sukses atau tidak, dan faktor itulah oleh Daniel Goleman disebut dengan istilah "Kecerdasan Emosional" (Emotional Intelligence). ${ }^{3} \mathrm{Hal}$ inilah yang ternyata menentukan apakah seseorang akan menonjol dalam kehidupan nyata, apakah memiliki atau merasakan hubungan dekat yang hangat, menjadi bintang di tempat kerjanya, atau sebaliknya. Rendahnya kecerdasan emosional dapat menghambat perkembangan intelektual dan menghancurkan karier, dan satu hal lagi bahwa kerugian terbesar diderita oleh anak-anak, yang mungkin akan terjerumus dalam resiko terserang depresi, agressivitas serta kejahatan dengan kekerasan.

Namun, belum lagi tuntas atau selesai diperbincangkan kecerdasan emosional, maka di awal abad ke 21, ditemukan satu kecerdasan baru yang disebut Kecerdasan Spiritual atau Spiritual Intelligence/Quotient. Temuan ini sempat menggegerkan dunia inteletual. Ini adalah kecerdasan jenis ketiga setelah Intelligence Quotient yang mulamula diperkenalkan oleh Wilhelm Stern dan berpengaruh kurang lebih 200 tahun, serta Emotional Quotient atau Emotional Intellegence yang ditemukan oleh Joseph deLoux dan kemudian dipopulerkan oleh Daniel Goleman.

\section{PENGERTIAN INTELEJENSI (INTELLIGENCE)}

Untuk lebih jelasnya pemahaman kita tentang intelejensi, berikut ini dikemukakan beberapa definisi sebagai berikut:

1. Claparde dan Stern mengatakan bahwa intelejensi adalah kemampuan untuk menyesuaikan diri secara mental terhadap situasi atau kondisi baru.

2. K. Buhler, intelejensi adalah perbuatan yang disertai dengan pemahaman dan pengertian.

3. David Wecheler, mula-mula ia memberikan definisi tentang intelejensi sebagai kapasitas untuk mengerti lingkungan dan kemampuan akal budi untuk mengatasi tantangan-tantangannya. Di kesempatan lain David memberikan lagi definisinya dengan mengatakan bahwa intelejensi adalah "kemampuan untuk bertindak secara terarah, berfikir secara rasional dan menghadapi lingkungannya secara efektif".

4. Alfred W. Munzert, mengemukakan bahwa intelejensi dan sikap intelektual adalah mencakup kecepatan memberikan jawaban dan penyelesaian dan kemampuan memecahkan masalah. 
Dari keempat definisi tersebut di atas dapat disimpulkan bahwa:

1. Intelejensi merupakan suatu kemampuan mental yang melibatkan proses berfikir secara rasional.

2. Tidak diamati secara langsung, melainkan harus disimpulkan dari berbagai tindakan nyata yang merupakan manifestasi dari proses berfikir.

3. Intelejensi hanya berkaitan dengan tindakan yang terarah pada penyesuaian diri terhadap lingkungan dan pemecahan masalah yang timbul daripadanya.

4. Ada unsur kecepatan di dalamnya untuk merespons sesuatu.

\section{KECERDASAN IQ, EQ, MENUJU KE SQ}

\section{Kecerdasan Intelektual (Intelligence Quotient)}

Di awal abad ke 20, satu-satunya kecerdasan yang dikenal adalah kecerdasan intelektual (IQ Intelligence Quotient) yakni suatu kecerdasan yang digunakan untuk berpikir logis-rasional, yaitu cara berpikir linier yang meliputi kemampuan berhitung, menganalisa sampai mengevaluasi dan seterusnya. Model kecerdasan ini memang banyak diilustrasikan dengan komputer yang memiliki tingkat IQ yang tinggi karena dapat beroperasi hampir tanpa kesalahan sama sekali. Manusia yang IQ tinggi, kecerdasan otaknya seringkali diperumpamakan dengan kecanggihan 'kecerdasan' komputer. Sampai-sampai pola berpikir IQ ini merasuk kuat ke dalam ingatan kolektif masyarakat, bahwa ber-IQ tinggi menjamin kesuksesan hidup, dan sebaliknya berIQ sedang-sedanga saja, apalagi rendah, begitu suram masa depan hidupnya.

Dalam dunia pekerjaan pun terkadang IQ menjadi hal yang menentukan diterima atau tidaknya seseorang dalam suatu instansi. Kita bisa lihat, persyaratan penerimaan pegawai dari suatu instansi pemerintah "berpendidikan Sarjana, IPK di atas 3,0 pengalaman kerja minimal 1 tahun, dan diutamakan sarjana eksakta". Persyaratan itu, yang selalu ada dalam penerimaan pegawai apa pun, lahir karena anggapan berlebihan terhadap kecerdasan matematika. Seakan-akan ada hubungan langsung dengan antara IPK 3,0 dengan keberhasilan pekerjaan. Persyaratan tersebut telah mengakibatkan kerugian yang tidak kecil bagi mereka yang memiliki IPK di bawah 2,0.

Walhasil, kurun waktu hampir 100 tahun lamanya IQ merupakan satu-satunya parameter kecerdasan manusia, sehingga seorang anak yang memiliki IQ yang tinggi menjadi kebanggan orang tua, padahal kecerdasan itu tidak menjamin seseorang berkembang dan sukses dalam hidupnya. Mengapa? Karena sebetulnya IQ tidak mengukur kreativitas, kapasitas emosi, nuansa spiritual dan hubungan sosial. Menurut Rober Copper dalam Taufik Pasiak "kecerdasan rapor" atau IQ itu hanya menyumbangkan sekitar 4 persen bagi keberhasilan hidup. ${ }^{4}$ Paling penting, keberhasilan 90 persen ditentukan oleh kecerdasan-kecerdasan lain. Yang lebih tragis, takaran IQ telah menghilangkan kesempatan berkembang bagi mereka yang memiliki IQ rendah, tetapi dengan kecerdasan lain yang dominan.

\section{Kecerdasan Emosional (Emotional Quotient)}

Di akhir abad ke 20 Daniel Goleman memperkenalkan kecerdasan baru yang disebut sebagai kecerdasan emosional atau EQ (Emotional Quotient), yang merupakan 
kecerdasan untuk mengendalikan emosi dan memberi empati sehingga seseorang dapat bereaksi secara wajar sesuai dengan stimulus atau peristiwa yang dihadapi. Lebih lanjut Goleman menjelaskan bahwa kecerdasan emosional adalah mencakup kesadaran diri dan kendali dorongan hati, ketekunan, semangat dan motivasi diri. Kecerdasan emosional adalah bagaimana membawa kecerdasan dalam kehidupan emosi sehingga emosi tadi membawa kepada kesuksesan, jadi inti dari kecerdasan emosional adalah pengendalian emosi dalam segala bentuk dan manifestasinya. Menurut Sudarsono menggambarkan bahwa pengendalian emosi adalah bagaimana kita dapat memahami perasaan orang lain, menerima sudut pandang mereka, menghargai perbedaan dalam cara berperasaan terhadap berbagai hal, termasuk pentingnya kemampuan untuk menjadi pendengar dan penanya yang baik. Seni bergaul juga menyangkut kemampuan dalam bekerja sama, memecahkan konflik, membuat kesepakatan. ${ }^{5}$ Itulah sebabnya mengapa orang yang memiliki EQ yang tinggi menjadikannya arif dan bijak, karena ia mampu merasakan, mengerti dan memahami perasaan orang lain.

Jika seseorang memiliki tingkat kecerdasan emosional yang tinggi, berarti ia mampu mengendalikan dorongan emosinya yang tinggi, berarti ia mampu mengendalikan dorongan emosinya, pandai membaca perasaan orang lain serta memelihara hubungan dengan baik dengan lingkungannya. Seperti halnya IQ yang perlu dilatih dan ditingkatkan lewat berbagai bentuk pendidikan, EQ-pun dapat dipertajam, antara lain, lewat pengenalan diri sendiri secara lebih mendalam. Ajaran Socrates "kenalilah dirimu" jelas menunjukkan inti kecerdasan emosional pada diri kita. Siapa yang mengenali (emosinya) dirinya, maka ia benar-benar mengenali Tuhannya" (al-Hadits), sebenarnya merujuk pada kecerdasan emosional.

Itulah sebabnya, paradigma yang dikonstruksikan oleh Goleman lebih mengacu pada kesadaran diri untuk mengendalikan emosi. Emosi sangat mempengaruhi kehidupan manusia ketika dia mengambil keputusan. Tidak jarang suatu keputusan diambil melalui emosinya. Tidak ada sama sekali keputusan yang diambil manusia murni dari pemikiran rasionya karena seluruh keputusan manusia memiliki warna emosional. 6

Bayangkan, jika emosi tak terkendali, orang biasanya selalu marah-marah. Padahal, sikap marah-marah justru mematikan bekerjanya nalar intelektual yang otomatis "membunuh" kekuatan IQ itu sendiri. Emosi sangat mempengaruhi kehidupan manusia ketika ia mengambil keputusan. Di sinilah ampuhnya EQ ketimbang IQ. Dalam praktek kerja sehari-hari, keampuhan EQ ini begitu terasa, penuh motivasi dan kesadaran diri, empati, simpatik, bersolidaritas tinggi, dan sarat kehangatan emosional dalam interaksi kerja. Inilah karakter orang yang ber EQ cerdas, yang jarang ditemukan pada orang yang ber IQ tinggi sekalipun. "Tipe murni ber IQ tinggi" dilukiskan Goleman bagai "karikatur kaum intelektual yang terampil di dunia pemikiran, tetapi canggung dalam kehidupan pribadi. ${ }^{7}$

Di sinilah pentingnya membawa kecerdasan emosional ke dalam dunia kerja. Kesimpulannya EQ terkadang memang lebih ampuh daripada IQ. Oleh karena itu, banyak orang yang ber IQ sedang-sedang saja justru sukses dalam hidupnya karena 
ternyata dibekali dengan EQ yang tinggi. Sebaliknya, banyak orang yang ber IQ tinggi justru sering gagal dalam hidupnya karena tingkat EQ-nya yang rendah.

Begitu fatalnya orang-orang yang tidak mempunyai kecerdasan emosional, dalam tulisan ini (seperti yang diungkapkan oleh Jalaluddin Rahman) ${ }^{8}$ diceritakan kisah nyata tentang pasangan suami istri dengan 4 anak, terdiri atas dua laki-laki, 2 perempuan. Berbeda dengan suaminya, sebut saja Pak Bekti, seorang pegawai negeri yang sangat bersahaja Bu Bekti menduduki jabatan direksi dalam sebuah perusahaan besar.

Di kantornya, Bu Bekti sangat disegani, baik oleh bawahan maupun jajaran setingkatnya. Bahkan, atasan langsungnya pernah mengatakan bahwa setiap kali mengamati cara Bu Bekti menangani permasalahan, ia sering bertanya dalam hati siapa yang sesungguhnya yang pantas disebut bos di kantornya. Karena kesibukannya, Bu Bekti nyaris tidak mempunyai waktu bagi keluarganya. Beruntung suaminya penuh perhatian, dan sangat mendukung karier istrinya. Kendati dari segi materi, kehidupan mereka tercukupi, dalam kenyataannya mereka menghadapi masalah besar: anak sulung menderita tuna grahita. Menyadari tugasnya sebagai ibu, Bu Bekti kemudian mengundurkan diri dari pekerjaannya agar dapat mencurahkan waktu lebih banyak bagi keluarganya. Keputusan yang sangat bijaksana.

Namun, merasa jenuh karena 'menganggur' Bu Bekti memutuskan untuk aktif menerjunkan diri dalam sebuah yayasan sosial yang khusus menangani anak-anak bernasib seperti putra sulungnya. Seperti dapat diduga, ditempatnya yang baru, Bu Bekti lagi-lagi menjadi sosok yang sangat disegani. Ia mencurahkan sebagian besar waktunya untuk yayasannya, sedemikian ketat jadwalnya sehingga membuat putranya kembali terlantar.

Dalam suatu pembicaraan dari hati ke hati dengan seorang psikolog sahabatnya, Bu Bekti mengeluh, mengapa dirinya kesulitan mengurus anak sendiri, mengapa ia merasa lebih mampu mengurus anak orang lain. Dengan sangat berhati-hati untuk tidak menyinggung perasaan $\mathrm{Bu}$ Bekti, sang psikolog kemudian mengungkapkan perbedaan antara IQ dan EQ. Melalui keberhasilan kariernya, ia yakin, IQ Bu Bekti sangat tinggi. Akan tetapi, bagaimana dengan EQ-nya? Tampaknya kecerdasan emosional Bu Bekti tidak setinggi kecerdasan otaknya; sebagai ibu ia kurang memiliki kepekaan, kesabaran, dan tenggang rasa bahkan terhadap anak kandungnya sekalipun.

Sebenarnya, teori Daniel Goleman ini menurut Jalaluddin Rahman dapat disimpulkan dalam peribahasa Arab: "Man shabara zhafara. Barang siapa yang bersabar, ia akan sukses". 9 Peribahasa ini bisa dikaitkan dengan kesimpulan bahwa orang yang sukses dalam hidupnya adalah orang yang memiliki kecerdasan emosional tinggi atau orang-orang yang sabar. Keadaan ini menunjukkan bahwa ada hubungan antara sukses dan kecerdasan. Kecerdasan emosional bisa dibentuk dengan melatih kesabaran dan tekun dalam menempuh perjalanan sabar.

\section{MENUJU KECERDASAN SPIRITUAL}

Di awal abad ke 21 ilmuwan suami istri Ian Marshall dan Danah Sohar telah memperkenalkan satu bentuk kecerdasan lagi yaitu spiritual intelligence sebagai aspek 
ketiga dari dua aspek kecerdasan sebelumnya (IQ, dan EQ). Sohar berpendapat bahwa pengenalan diri dan terutama kesadaran diri adalah kesadaran internal otak, menurutnya, proses yang berlangsung dalam otak sendirilah tanpa pengaruh pancaindra dan dunia luar yang membentuk kesadaran sejati manuasia. ${ }^{10}$ Bahkan, penemunya, Danah Sohar dan Ian Marshall menyebut SQ sebagai The Ultimate Intelligenve (puncak kecerdasan). ${ }^{11}$ Suatu kecerdasan yang benar-benar luar biasa. Apa sebenarnya SQ ini? Sampai-sampai penemunya mengatakan sebagai puncak kecerdasan?

Di atas sudah dikemukakan bahwa, jika IQ bersandarkan nalar, rasio intelektual, sementara EQ pada emosi, maka hakikat sejati SQ disandarkan pada The soul's intelligence. Kecerdasan Jiwa, hati yang menjadi intisari SQ.

Karena itu, menurut Sukidi "pekik" SQ adalah suara hati. ${ }^{12}$ Suara yang paling jernih dalam hiruk pikuk kehidupan kita, yang tak bisa ditipu oleh siapa pun, termasuk diri kita sendiri. Kebenaran sejati sebenarnya terletak pada suara hati ini, yang menjadi suara SQ. Karenanya, SQ menyingkap kebenaran sejati yang lebih sering tersembunyi di tengah adegan-adegan hidup yang serba palsu dan menipu.

Lebih lanjut dikemukakan bahwa Spiritual Intelligence mengajak mendalami dan mempelajari hakikat kasih sayang yang justru akan bermuara dari diri kita sendiri atau hati kita. Michal Levin mengemukakan bahwa SQ akan merupakan perpaduan tentang apa yang kita hayati perihal rasa kasih sayang yang bersumber dari hati kita dengan segala yang berkaitan dengan mentalitas kita. ${ }^{13}$

Untuk mengetahui lebih lanjut bahwa SQ sebagai puncak kecerdasan, Penulis mengutip pendapat A. Husni Tanra dalam makalahnya yang berjudul Paradigma Kuantum dan Kecerdasan Spiritual, beliau mengemukakan bahwa secara anatomis ke 3 kecerdasan (sebagaimana yang penulis kemukakan di atas) terletak dalam otak dan ketiga kecerdasan tersebut memiliki sinergisme yang tinggi, walaupun ada yang lebih dominan daripada yang lainnya. Seseorang yang memiliki IQ yang tinggi belum tentu memiliki EQ atau SQ yang tinggi. Sebaliknya seseorang yang memiliki EQ yang tinggi berpeluang untuk mengembangkan IQ secara optimal tapi SQ-nya belum tentu. Sedangkan seseorang yang memiliki SQ yang tinggi secara otomatis memiliki IQ dan EQ yang tinggi pula. Itulah sebabnya mengapa kecerdasan spiritual disebut juga sebagai "Ultimate Intelligence", puncak kecerdasan atau kecerdasan yang paling tinggi. ${ }^{14}$ Ini berarti bahwa makna kehidupan merupakan tujuan hidup yang pertama dan utama bagi umat manusia. Hanya orang-orang yang cerdas secara spiritual yang mampu memberi makna dalam hidupnya, dan semua orang berpotensi yang sama memberi makna hidupnya.

Hal ini sejalan dengan penjelasan M. Quraish Shihab, bahwa "kecerdasan spiritual melahirkan kemampuan untuk menemukan makna hidup, serta memperhaluas budi pekerti". 15 Seseorang dapat memberi makna hidupnya dalam kapasitas apapun yang dimilikinya. Seseorang tak perlu menunggu untuk mencapai kedudukan atau pendidikan yang tinggi baru memberi makna kehidupannya, dengan kata lain setiap orang berpeluang yang sama untuk memberi makna dalam hidupnya apapun kapasitasnya. Seperti dikemukan oleh Ary Ginanjar Agustian, kecerdasan spiritual adalah 
kemampuan untuk memberi makna spiritual terhadap pemikiran, perilaku dan kegiatan serta mampu menyenergikan IQ, EQ dan SQ secara komprehensif. ${ }^{16}$

Lebih lanjut Ary Ginanjar Agustian ${ }^{17}$ memberikan contoh, Erwyn bekerja di sebuah perusahaan otomotif sebagai seorang buruh. Tugasnya memasang dan mengencangkan baut pada jok pengemudi. Itulah tugas rutin yang sudah dikerjakannya selama hampir sepuluh tahun. Karena pendidikannya hanya setingkat SLTP, maka sulit baginya untuk meraih posisi puncak. Pernah ditanya "bukankah itu suatu pekerjaan yang sangat membosankan?" ia menjawab dengan tersenyum, "tidakkah ini pekerjaan mulia, saya telah menyelamatkan ribuan orang yang telah mengemudikan mobil-mobil ini? Saya mengencang-kuatkan seluruh kursi pengemudi yang mereka duduki, sehingga mereka sekeluarga selamat".

Esok harinya ditanya lagi: "Mengapa anda bekerja begitu giat, upah Anda, kan tidak besar? Mengapa Anda tidak melakukan mogok kerja seperti yang lain untuk menuntut kenaikan upah?" masih dengan senyum dan menjawab: "saya memang senang dengan kenaikan upah seperti teman-teman yang lain, tetapi saya pun memahami bahwa keadaan ekonomi memang sedang sulit dan perusahaan pun terkena imbasnya. Saya memahami keadaan pimpinan perusahaan yang juga tentu dalam keadaan kesulitan, bahkan terancam pemotongan gaji seperti saya. Jadi kalau saya mogok kerja, maka itu hanya akan memperberat masalah mereka, masalah saya juga." Lalu ia melanjutkan pembicaraan sambil tersenyum. "Saya bekerja, karena prinsip saya adalah 'memberi', bukan untuk perusahaan, namun lebih kepada pengabdian bagi Tuhan saya."

Erwyn mampu memaknai pekerjaannya sebagai ibadah, demi kepentingan umat manusia dan Tuhan yang sangat dicintainya. Ia berpikir secara integralistik dengan memahami kondisi perusahaan secara keseluruhan, situasi ekonomi, dan masalah atasannya, dalam satu kesatuan yang integral. Erwyn berprinsip dari dalam, bukan dari luar, ia tidak terpengaruh oleh lingkungannya. Erwyn adalah seorang raja atas jiwanya sendiri yang bebas merdeka. Sebuah penggabungan atau sinergi antara rasionalitas dunia (EQ dan IQ) dan kepentingan spiritual (SQ). hasilnya adalah kebahagiaan dan kedamaian pada jiwa Erwyn. Ia menjadi asset perusahaan yang sangat penting dan "rahmatan lil alamiin" bagi sekitarnya.

Di sinilah letak keadilan Tuhan (Allah swt) karena nilai amal ibadah seseorang sangat tergantung pada niatnya, ketulusan dan keikhlasannya. Seorang seperti Erwyn yang hanya tukang memasang baut pada mobil bahkan hanya berpendidikan SLTP, dapat berpeluang memiliki amal ibadah yang sama dengan seorang gubernur atau presiden karena keduanya melakukan tugasnya dengan segala ketulusan dan keikhlasannya karena Allah.

Kecerdasan ini dilandasi oleh ketulusan, keikhlasan dan kebenaran tanpa pamrih, yang sumber inspirasinya berasal dari Allah swt. Dalam psikologi ketuhanan, SQ kurang lebih nafsu al muthmainnah. Jiwa yang damai dan tenang, yang bisa menjalin kontak spiritual dengan Ilahi Rabbi. ${ }^{18}$

Zohar selaku penemu SQ, mengartikan makna kehidupan sebagai suatu kebutuhan biologis dan psikologis yang harus dipenuhi dalam mencapai kebahagiaan 
dunia. Namun belum bersifat trasendental, sehingga masih terasakan adanya kebuntuan, sehingga kebahagiaan yang dicapai terbatas dalam kebahagiaan hidup di dunia, tapi belum memiliki kebahagiaan dunia dan akhirat yang merupakan tujuan akhir dari berbagai pemeluk agama, khususnya pemeluk agama Islam. ${ }^{19}$

Oleh karena itulah maka beberapa cendekiawan muslim menafsirkan SQ, sebagai kecerdasan yang berakar dari mata hati atau fitrah yang merupakan roh suci tersebut yang ditiupkan Tuhan sewaktu dalam kandungan (QS: 7: 172). Meminjam istilah Quraish Shihab, SQ dapat melahirkan mata ketiga dan indra keenam. Jalaluddin Rumi menggambarkan SQ sebagai mata hati yang bersumber dari kedalaman hati yang suci yang tidak pernah bohong baik oleh orang lain maupun dirinya sendiri. Mata hati yang suci itu 70 kali lebih tajam dalam melihat kebenaran dari dua indra (mata) penglihatan seseorang. Bahkan Ibn Paquda menggambarkan bahwa "seseorang yang mengenal Tuhannya, akan melihat-Nya tanpa mata, akan mendengarNya tanpa telinga, akan merasakan-Nya tanpa alat perasa, dan akan memahami-Nya tanpa penalaran".

\section{IMPLIKASI SQ DALAM KEHIDUPAN SOSIAL}

Apakah SQ hanya berurusan dengan hal-hal yang berbau spiritual belaka? Jawabannya tidak. Pancaran SQ memantul ke luar, ke etika sosial. Kecerdasan spiritual tidak hanya sekedar kecerdasan dan kesadaran. Tapi yang paling penting adalah perilaku individu dan social.

Husni Tanra menggambarkan bahwa seseorang yang SQ-nya tinggi menyadari ketika dia merugikan orang lain itu berarti dia merugikan dirinya sendiri, ketika dia melampiaskan kemarahan pada orang lain itu berarti dia mencemari jiwanya sendiri. Ketika dia melakukan perusakan pada lingkungan maka itu berarti dia telah merusak sumber kehidupannya sendiri. Demikian juga ketika dia mengasingkan diri menjauh dari lingkungan sosialnya, berarti dia telah mengasingkan dirinya menjauh dari lautan energi dan potensi yang menjadi pusat dirinya sendiri. ${ }^{20}$

Walaupun kecerdasan spiritual tersebut tidak berbanding lurus dengan kealiman seseorang, namun upaya mempertahankan atau meningkatkan kecerdasan spiritual dapat dilakukan melalui penghayatan dan pengamalan agama yang benar, agama apapun yang dianut, karena setiap agama pada dasarnya mengajarkan kebenaran. Menurut ajaran Islam, bahwa penghayatan dan pengamalan yang didasarkan pada 6 rukun iman sebagai pembuat mental dan 5 rukun Islam sebagai pembentuk karakter yang merupakan salah satu upaya peningkatan kecerdasan spiritual seseorang. Dengan kata lain sebagai umat Islam kita memiliki potensi yang besar untuk memiliki kecerdasan spiritual yang tinggi.

Namun sayangnya tanda-tanda kecerdasan itu belum nampak secara merata di negara yang mayoritas pemeluknya Islam, termasuk Indonesia. Walaupun banyak tanda seseorang memiliki SQ yang tinggi namun ada 5 tanda-tanda umum yang utama, yakni: 
1. Selalu ingin berbuat baik dan memberi makna kehidupannya.

2. Tidak sombong tetapi rendah hati.

3. Humanistik dan menghargai semua orang, agama apapun yang dianut

4. Memiliki empati yang tinggi terhadap orang lain.

5. Selalu bersyukur, apapun kapasitas yang dimilikinya. ${ }^{21}$

\section{SIMPULAN}

Dalam era informasi dan teknologi dewasa ini seseorang dapat memiliki berbagai kemudahan-kemudahan sebagai sumbangsi produk teknologi yang semakin maju. Dengan kecerdasan intelektualnya manusia mampu memiliki apa saja yang diinginkannya, kini banyak orang yang sukses segala-galanya sehingga mampu mengumpulkan harta yang berlimpah, tapi kemudian ia merasa buntu dan bertanya untuk apa harta sebanyak ini, untuk apa hidup ini, atau untuk apa saya lahir di dunia ini? Maka kehadiran kecerdasan spiritual adalah sebuah alternatif yang dianggap mampu untuk menjelaskan kompleksitas permasalahan dunia dewasa ini ditengah kemelut krisis makna. Karena kecerdasan spiritual bukan sekedar hanya bertanya tentang "apa" yang kita pelajari atau "bagaimana" kita bertingkah laku, melainkan tentang "mengapa" kita melakukan tindakan kita. Ini berarti bahwa kecerdasan spiritual mengajak kita untuk memberi makna kehidupan ini. Hanya orang-orang yang cerdas secara spiritual yang mampu mengenal penciptanya, dan hanya dengan mengenal penciptanya seseorang mengerti akan tujuan hidupnya untuk memberi makna kehidupan.

\section{CATATAN AKHIR}

1. Taufik Pasiak, Revolusi IQ / EQ / SQ antara Neurosains dan Al-Quran, Bandung: Mizan, 2005, h. 120 .

2. Sukidi, New Age Wisata Spiritual Lintas Agama, Jakarta: PT Gramedia Pustaka Utama, 2001, h. 133.

3. Daniel Goleman, Emotional Intelligence, Jakarta: Gramedia, 1997.

4. Taufik Pasiak, op. cit., h. 121.

5. Soemarno Soedarsono, Menepis Krisis Identitas Penyamaian Jati Diri, Jakarta: Gramedia, 2001, h. 40.

6. Jalaluddin Rakhmat, Meraih Cinta Ilahi Pencerahan Sufistik, Bandung: Remaja Rosdakarya, 2000, h. 240.

7. Sukidi, op. cit., h. 136.

8. Jalaluddin Rakhmat, op. cit., h. 242.

9. Ibid.

10. Taufik Pasiak, op. cit., h. 27.

11. Sukidi, op. cit., h.139

12. Ibid.

13. Ibid.

14. A. Husni Tanra, "Paradigma Kuantum dan Kecerdasan Spiritual", Makalah, pada Acara Milad Ke 48 Universitas Muslim Indonesia Makassar, 2002, h. 23. 
15. M. Quraish Shihab, Dia Dimana-mana: "Tangan" Tuhan di Balik setiap Fenomena, Jakarta: Lentera Hati, 2005, h. 136.

16. Ary Ginanjar Agustian, ESQ Emotional Spiritual Quotient, Jakarta: Arga, 2006, h. 47.

17. Ibid.

18. Sukidi, op. cit.

19. Ibid.

20. A. Husni Tanra, op. cit.

21. Ibid.

\section{DAFTAR PUSTAKA}

Departemen Agama. Al-Qur'an dan Terjemahnya. Semarang: Toha Putra Semarang, 1989.

Agustian, Ary Ginanjar. ESQ Emotional Spiritual Quotient. Jakarta: Arga, 2006.

Goleman, Daniel. Emotional Intelligence. Jakarta: Gramedia, 1997.

Pasiak, Taufik. Revolusi IQ / EQ / SQ Antara Neurosains dan Al-Quran. Bandung: Mizan, 2005.

Rakhmat, Jalaluddin. Meraih Cinta Ilahi Pencerahan Sufistik. Bandung: Remaja Rosdakarya, 2000.

Shihab, M. Quraish. Dia Dimana-mana: "Tangan" Tuhan di Balik setiap Fenomena. Jakarta: Lentera Hati, 2005.

Sukidi. New Age Wisata Spiritual Lintas Agama. Jakarta: PT Gramedia Pustaka Utama, 2001.

Soedarsono, Soemarno. Menepis Krisis Identitas Penyamaian Jati Diri. Jakarta: Gramedia, 2001.

Bowell, Richard A. The 7 Steps of Spiritual Quotient (Jalur Praktis Mencapai Tujuan, Kesuksesan, dan Kebahagiaan). Jakarta: Gramedia, 2006.

Rus'an. Kumpulan Diktat Psikologi Pendidikan pada Program Pascasarjana Universitas Negeri Makassar. (Terjemahan dari buku Educational Psychology oleh Paul Eggen), 2002.

Tanra, A Husni. "Paradigma Kuantum dan Kecerdasan Spiritual." Makalah. Dipresentasikan pada Acara Milad ke-48 Universitas Muslim Indonesia Makassar, 2002. 